\title{
Erratum to: Agro-ecological nitrogen management in soils vulnerable to nitrate leaching: a case study in the Lower Suwannee Watershed
}

\author{
Sampson Agyin-Birikorang • Yoana C. Newman • \\ Augustine K. Obour • Gabriel N. Kasozi
}

Published online: 5 February 2012

(C) Springer Science+Business Media B.V. 2012

\section{Erratum to: Nutr Cycl Agroecosyst (2012) 92:91-105 DOI 10.1007/s10705-011-9474-9}

In the original publication of the article, some sections were cited liberally from the previously published work. Authors regret for this error and would like to include the following sentence under the "Statistical Analysis" in the "Materials and Methods" section:

"Analyses of the yield response model and economically optimum fertilizer rates, were carried out following the procedure described by Valkama et al. (2011)".

\section{Reference}

Valkama E, Uusitalo R, Turtola E (2011) Yield response models to phosphorus application: a research synthesis of Finnish field trials to optimize fertilizer P use of cereals. Nutr Cycl Agroecosyst 91:1-15. doi:10.1007/s10705-011-9434-4

The online version of the original article can be found under doi:10.1007/s10705-011-9474-9.

S. Agyin-Birikorang $(\bowtie)$

International Fertilizer Development Center,

P.O. Box 2040, Muscle Shoals, AL 35662, USA

e-mail: sagyin-birikorang@ifdc.org

Y. C. Newman

Agronomy Department, University of Florida,

P.O. Box 110500, Gainesville, FL 32611-0500, USA

\author{
A. K. Obour \\ Plant Sciences Department, University of Wyoming \\ James C. Hageman SAREC, 2753 State HWY 157, \\ Lingle, WY 82223, USA \\ G. N. Kasozi \\ Geology Department, University of Florida, \\ P.O. Box 112120, Gainesville, FL 32611-2120, USA
}

